\title{
纎維の配列度に関する研究“第3 報)
}

(昭和31.年10月5日受理) 全是并谷和十郎兹

\section{摘}

要

\section{研 究 目 的}

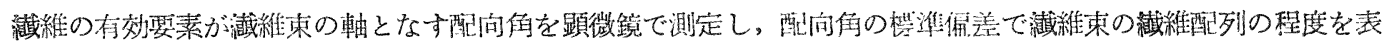
示寸る新しい測定法について考察した。

\section{研 究 結 果}

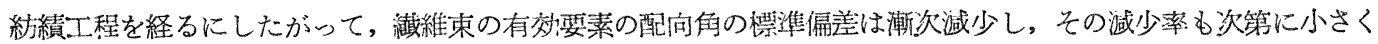
なることが認められた，㵶維束の配向角の分布は工程を経るにしたがッて，順次正規型—不正規型一一正㚘型に

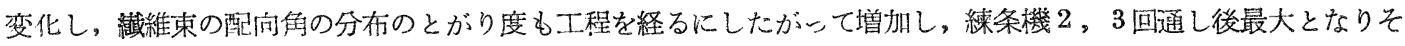
の後次第に減少することが認められた。

\section{1. 緒}

\section{言}

瀻維の有效要素の散布度を測定して, 繊維束の中の裁 維配列の程度を定量的に示す方法について述べる。この 種の研究として Morton らはスライバにトレーサ繊維 を混合して、その形状を描画し，スライバ軸方向闪へ緎 維の本均射影長と平均瀻維長の比で繊維配列度をあらわ しまたトレーサ繊維の形状を 5 種に分類し，各種の㵶 維の增減によって瀻維の配列の程度を比較している。

瀻維の散布度を間接に測定する方法として，石川民は 梳毛スライバ表面の光沢度で瀻維本行度を比較し,

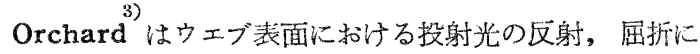
よる光の光電池出力を測定し，次式で㰇維配列の程度を 比較している.

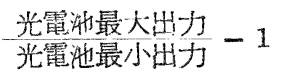

Mortonの方法はトレーサ繊維を用らるだめ不便であ り，石川氏及び Orchard の方法は投射光を使用してい るため，繊維の形状との関係が明確でない。

よって本交に沏いては繊維を鎻の上了に多くの有效要 素がつながりあってできているものと見なし，有效要素 が㵶稚束の長さ方向となす配向牦を測定し，配向角の散 布度あるいは配向角の余弦の平均值で織維配列の程度を

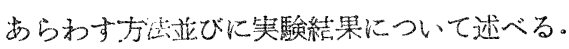

\section{2. 実 験 万 法}

顕微鏡にアッべ描画裝置を取付けて，繊維束の䓂面を
観察し,視野にあらわれる纎維数を多くし,描画中の瀻維 の変形を阻止するように, 纎維束の上にカバ グラス(18 $\times 18 \mathrm{~mm}^{2}, 127 \mathrm{mg}$ ) を置いて, 視野內の纎維の輪郭を 描画した、ラップの断面繊維を描画する場合は，その厚 さ等しい長方形の容器を作りスライバの場合はとの 橫断面とほぼ同形で，矩径を含む軸方问を切口とする半 棈円筒の容器を作り。これらの中に西洋紙にはさんだ緎 維束を入れ，容器の切口に出た部分を四洋紙と共に鉄で 切断する。ロービングの場合は、これらと永ば同径で, 弾性の極限の大きいパイプ(例壳ばゴム,ビニール)にそ ラ入し，中心軸に沿ってパイプと一緒沉銥で切断する。

これらの断面をガラス板で押え，切断のとき压縮され た㵶維束が柱は原形に膨化した後。断面にあらわれた瀻

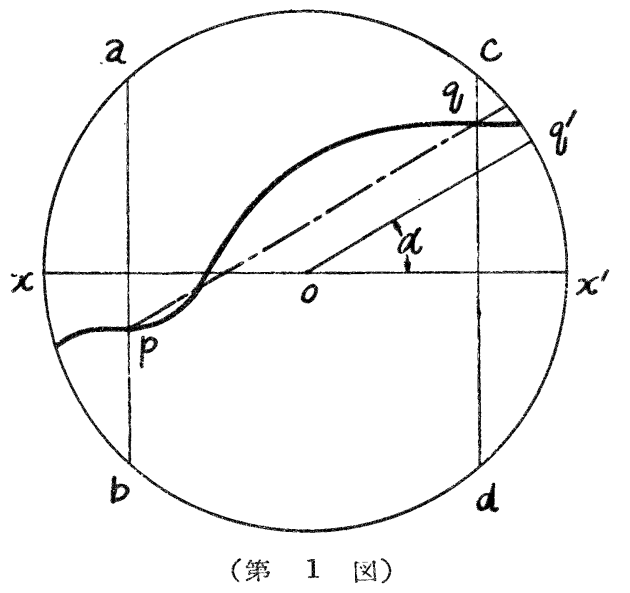

* On the Fiber Orientation. Part 3.

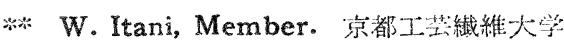


維の形状を描画する。

㩲画円の中の繊維の長さの差を比較的少なくするため 第1図のよ5に描画円0の中央部で直径の $\% 3$ 以內にあ

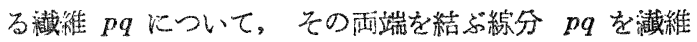
の有效姴素と兒なした。断面の埸合には視野にあらわれ る瀐維の長さは著しく短いから,ラップ,カードスライ バなどの㙏合は犆径の1/4位の長さのものまで測定した。

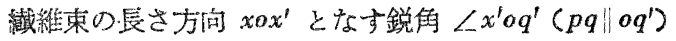
を配向角とし， $\angle x^{\prime} a q^{\prime}$ が㨁線 $x o x^{\prime}$ の上方にあるとさは 正，下方にあるときは奂とすれば，配向角の变域は( $90^{\circ}, 90^{\circ}$ ) となるから，級間隔を $10^{\circ}$ とし，それぞれの 階級に属する頻度数を計測し，配向角の樏潐候差及び配 向角の余昡の本均值をもとめ，これらの数値で瀻維配列 の程度を比較した。

特別の壦合を除き顕徽鏡の倍率は 50 倍にして, 視野 の真往は $2.1 \mathrm{~mm}$ であるから，有效慗菜の長さはほぼ 1.4 mm であるが，瀻維配列の悪い瀻維束の断面の有効 姴素の與さは $1.0 \mathrm{~mm}$ である。

\section{3. 実驗結果}

(A) 試料の位置, 有效要素の長さ及び 顕微鏡の倍率による影鄉

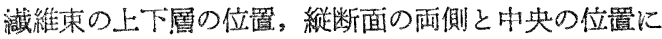
扣ける有效要素の散布度の差暴, 有效巽素の長さ及び顕 微鏡の倍率が有效要素の散布度に及ほすす影響について測 定した。

同一の試料については描画円数 8 個, 円內の描画瀻維 数 25 本, 総標本数 200 個について計測した。

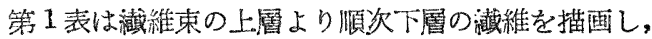

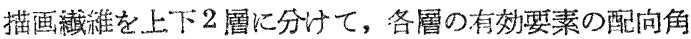
の本均值，標潐偏差を計測したもので，仕上ラップ，ス ラッビングでは上下翼の標潐偏差の差が少なく,カード 叉び第1練条スライバには柏当の差が認められる。

\section{(第 1 表)}

\begin{tabular}{|c|c|c|c|c|c|c|}
\hline \multirow{2}{*}{ 試 } & \multicolumn{3}{|c|}{ 平均值 (度) } & \multicolumn{3}{|c|}{ 標準侱差(度) } \\
\hline & 上閴 & 下犀 & 平圴 & 上犀 & 下屬 & 平均 \\
\hline 仕上ラップ & 8 & -6 & 1 & 46 & 42 & 44 \\
\hline $\begin{array}{l}\text { カ } \\
\text { スイド }\end{array}$ & -4 & -2 & -3 & 37 & 28 & 33 \\
\hline 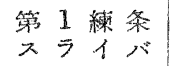 & -2 & 0 & -1 & 30 & 20 & 25 \\
\hline スラッビング| & -14 & -12 & -13 & 19 & 13 & 16 \\
\hline
\end{tabular}

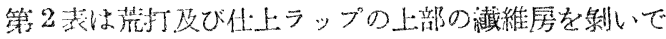

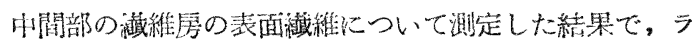

(第 2 表)

\begin{tabular}{|c|c|c|c|c|}
\hline \multirow[b]{2}{*}{ 試 } & \multicolumn{2}{|c|}{ 中間繊維居表面 } & \multirow{2}{*}{ 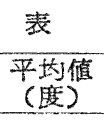 } & \multirow{2}{*}{ 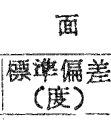 } \\
\hline & $\begin{array}{l}\text { 平夶值 } \\
(\text { (度) }\end{array}$ & $\begin{array}{c}\text { 醥集偏差 } \\
\text { (度) }\end{array}$ & & \\
\hline 濳打ラップ & -1 & 42 & -3 & 45 \\
\hline 仕上ラップ & -2 & 38 & 3 & 39 \\
\hline
\end{tabular}

ップ䒧面の場合と著しい差は諗められない。

仕上ラップ表面の瀻維配列は悪く，スラッビングは撚 りにより表面瀻維の变形の回復が束縛されているが， ス ライバでは䌖維の受けた変形が大きく，しかも表面驖維 相互の摩擦抵抗が少ないために上述の上うな㮔準偏差の 这が生じたすのと考えられる。

第 3 表はカードスライバの綐断面の横方向等間嵒の 位置に打ける有效要素について測定したもので，位置に よる変化の傾向は認められない.したがって瀻䧽の変形 の回復の著しいのは最上雷部の瀻維であることが推察さ れる。

(第 3 表)

\begin{tabular}{l|r|r|r|r|r|r|r}
\hline 位 圆 & \multicolumn{1}{|c|}{1} & \multicolumn{1}{|c|}{2} & 3 & 4 & 5 & 6 & 7 \\
\hline 平圴 值 (度) & 2 & -1 & -1 & 2 & 1 & -1 & 1 \\
標準偏差 (度) & 25 & 22 & 24 & 24 & 22 & 24 & 24 \\
\hline
\end{tabular}

描画した驖維の有效要素の長さによる散布度の影響を 考察するために，倍率25倍の顕微鏡 (垁視野直径 $6 \mathrm{~mm}$ ) を用い，描画円の中块部で視野の直径 $1,2,4,6 \mathrm{~mm}$ に相当する円內の有教要素について訓測した。

第 4表のよ5に有效要素の長さが大になるにしたがっ て, 櫒準偏差は多少小さくなることが認められる。

(第 4 表)

\begin{tabular}{|c|c|c|c|c|c|}
\hline 試 料 & $\begin{array}{c}\text { 視野の㨁径 } \\
(\mathrm{mm})\end{array}$ & 1 & 2 & 4 & 6 \\
\hline カード & 平均倠 (度) & 3 & 1 & 3 & 2 \\
\hline スライバ & 標準偏差 (度) & 28 & 27 & 25 & 24 \\
\hline 第 2 練条 & 平均 值 (度) & -4 & -5 & -3 & -5 \\
\hline スライパ & 標準偏差 (度) & 18 & 17 & 15 & 14 \\
\hline
\end{tabular}

第 5 表はカード スライバの同じ位䪅を顕微鏡の倍率 を换えて描画し，倍率の影響を示したもので，倍㨌が大 きくなるにしたがって，铎準偏差は增加することが認め られる。

影徽鏡の倍率を大にすると焦点の深さが浅くなるから

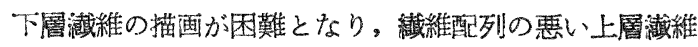
の久を描画する結果となること攻び顕微鏡の倍率が大き いと視野の直径が減少し，有效要素の長さが小となるこ とに起因するものと考えられる。 
（第 5 表）

\begin{tabular}{|c|c|c|c|c|c|c|c|c|c|c|}
\hline \multirow{2}{*}{ 試 } & \multirow{2}{*}{ 料 } & & \multicolumn{2}{|c|}{25} & \multicolumn{2}{|c|}{35} & \multicolumn{2}{|c|}{50} & \multicolumn{2}{|c|}{100} \\
\hline & & $\begin{array}{c}\text { 有効要素の長さ } \\
(\mathrm{mm})\end{array}$ & $6^{*}$ & 4 & $3 *$ & 2 & $2 *$ & 1.5 & $1.5 *$ & 1 \\
\hline \multirow{2}{*}{ カード } & \multirow{2}{*}{ スライバ } & 平圴值 (度) & 2 & 3 & 1 & 2 & 0 & 0 & 0 & 0 \\
\hline & & 標 準 偏 差（度） & 24 & 25 & 28 & 29 & 31 & 31 & 32 & 32 \\
\hline \multirow{2}{*}{\multicolumn{2}{|c|}{ 第 2 練条スライバ }} & 平均 值 (度) & -5 & -3 & -2 & -2 & -4 & -3 & -2 & -2 \\
\hline & & 標準 偏 差（度） & 14 & 15 & 15 & 16 & 17 & 18 & 19 & 19 \\
\hline
\end{tabular}

（注） * は描画円內の纎維の全長について測定した

(B) 各工程繊維束の配向角の掼淮偏差

綿及びスフ紡績各工程の繊維束について, その表面及 び断面の瀻維の有效要素の配向角の覆準偏美を計測した 第 6 表の綿鐵維束は第 1 報第 1 表の紡績条件で製造した もので，第7表のスフ スライバはT社で製造されたも のである. 各試料について描画円 12 個, 視野內の描画 瀻維数 25 , 全殹本数 300 とした。

第 2,3 函は綿瀻維束の表面及び断面の繊維の配向角 （第 6 表）

\begin{tabular}{|c|c|c|c|c|c|c|}
\hline \multirow{2}{*}{ 試 } & \multirow[b]{2}{*}{ 料 } & 表 & 面 & \multicolumn{2}{|c|}{ 断 } & 面 \\
\hline & & $\begin{array}{l}\text { 平咕値 } \\
\text { (度) }\end{array}$ & $\begin{array}{l}\text { 標準僱差 } \\
\text { (落) }\end{array}$ & \multicolumn{2}{|c|}{$\begin{array}{l}\text { 平芯值 } \\
\text { (度) }\end{array}$} & $\begin{array}{l}\text { 標準偏差 } \\
\text { (度) }\end{array}$ \\
\hline 原 & & 1 & 47.5 & \multicolumn{2}{|r|}{0} & 30.5 \\
\hline \multirow{3}{*}{\multicolumn{2}{|c|}{$\begin{array}{l}\text { 荒打 } ッ 7^{\circ} \\
\text { 仕上ラップ } \\
\text { カードスライバ }\end{array}$}} & -3 & 46.5 & \multicolumn{2}{|r|}{2} & 26 \\
\hline & & 3 & 43.5 & \multicolumn{2}{|r|}{2} & 25 \\
\hline & & 0 & 31 & \multicolumn{2}{|r|}{0} & 23 \\
\hline \multicolumn{2}{|c|}{ 第 1 練条スライバ } & 0 & 24 & \multicolumn{2}{|c|}{-1} & 17 \\
\hline \multicolumn{2}{|c|}{ 第 2 練条スライバ } & 0 & 20 & \multicolumn{2}{|r|}{0} & 15 \\
\hline \multicolumn{2}{|c|}{ 第3 練条スライバ } & 0 & 17 & \multicolumn{2}{|r|}{1} & 13 \\
\hline \multirow{2}{*}{\multicolumn{2}{|c|}{$\begin{array}{l}\text { スッビン } \\
\text { ロ } ー \text {-ビ ע }\end{array}$}} & -13 & 14 & \multicolumn{2}{|r|}{0} & 11.5 \\
\hline & & -13 & 11.5 & \multicolumn{2}{|r|}{1} & 10 \\
\hline & & （第 & \multicolumn{4}{|l|}{7 表) } \\
\hline & & & 表 & 面 & 断 & 面 \\
\hline 原料 & 試 & 料 & \begin{tabular}{|l} 
平地値 \\
(度)
\end{tabular} & 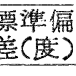 & $\begin{array}{l}\text { 平均值 } \\
\text { (度) }\end{array}$ & 值標隻俯 \\
\hline$\overbrace{\text { 並 }}$ & 荒打 ラ & ッ プ & 0 & 46.5 & -1 & 17.6 \\
\hline 普 & 仕上 & ッ プ & -2 & 42.3 & -1 & 14.2 \\
\hline 通 & カードス & ライバ & 2 & 32 & 1 & 13 \\
\hline$F_{x}$ & 第 1 練条ス & ライバ & 0 & 22.4 & 1 & 10.7 \\
\hline to & 第 2 練条入 & ライバ & 1 & 19.8 & -1 & 10.5 \\
\hline$\Xi^{7}$ & 第 3 練条ス & ライバ & 3 & 12.4 & 0 & 8.1 \\
\hline & 荒打 ラ & ッ $フ^{\circ}$ & 2 & 44.2 & 3 & 23.1 \\
\hline 胥 & 仕 上 & ッ プ & 2 & 42.3 & 2 & 14.7 \\
\hline 马縮 & カードス & ライバ & 1 & 30.9 & 2 & 15.1 \\
\hline$v$ & 第 1 練条 & ライバ & -1 & 23.7 & 2 & 11.2 \\
\hline $\begin{array}{l}5 \\
5 \\
5\end{array}$ & 第 2 練条入 & ライバ & 0 & 20.7 & 1 & 10.8 \\
\hline & 第 3 練条ス & ライバ & 1 & 15.2 & -1 & 10 \\
\hline
\end{tabular}

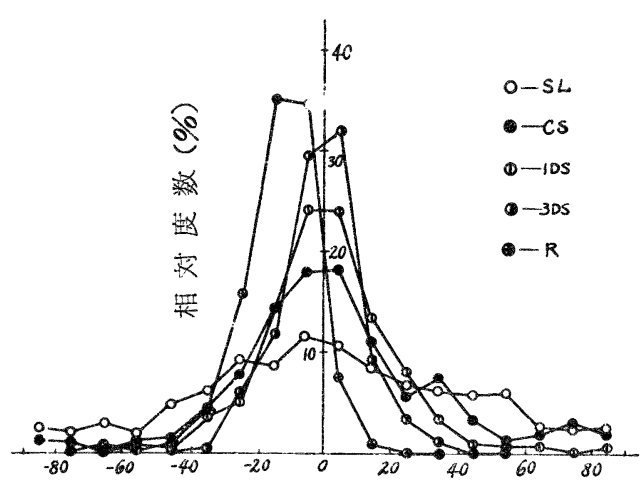

配向角 (显)

(第 2 図)

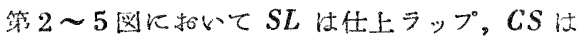
カードスライバ， $1,3 D S$ 汕第 1,3 練条スラ イバ， $R$ 注ロービングである

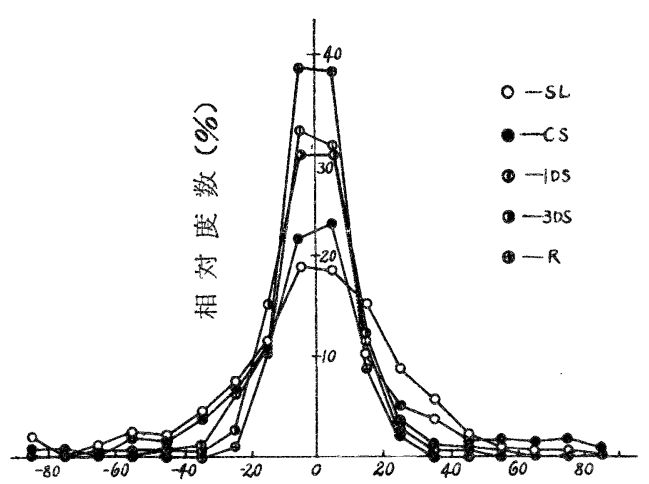

配 向 角 (等)

（第 3 図）

の相対度数分布を示したもので，工程を経るにしたがの て有好要素は㵶維束の長さ方向（粗系の表面緎維は撚り 角の方向）に密集することが認められる。

第 $6 ， 7$ 表のよ5に配向角の標準偏差む.工程を経るに したがって漸次減少し, 灌維配列が良好となる。殊に力 一ド攻び練条機 1 回通しの效果か顕著であって，工程を 経る心したがって效果は濑淢し，スラッビング，ロービ ングでは能和值に近づくことが認められる。 
各試料の配向角の不均值はほとえど0であるが，粗系 はいずれる130で,これは撚りによる影響である.

ラップの表面及び断面の標淮偏差の差は大であるが, 工程を経るにしたがって潮減し，粗糸ではことにきん少 になる.

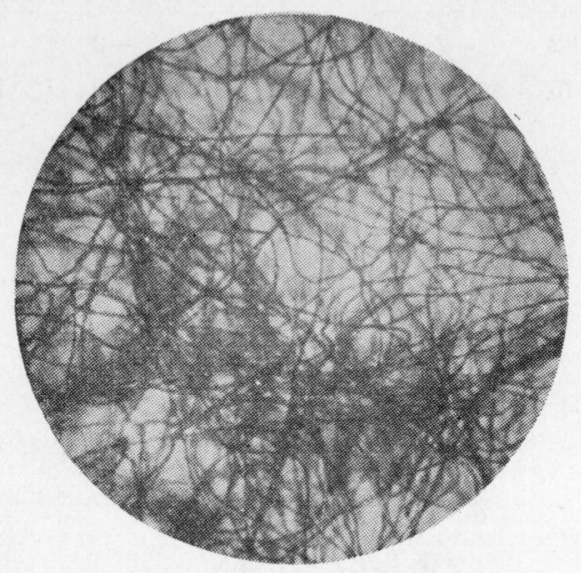

(写真 1) 仕上

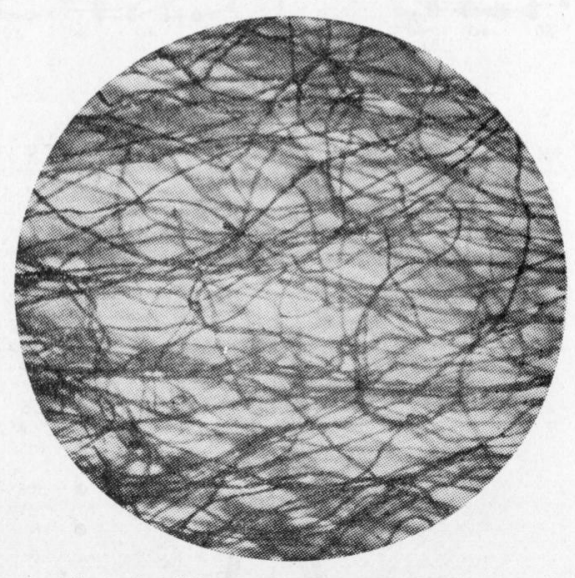

(写真 2)カードスライバ

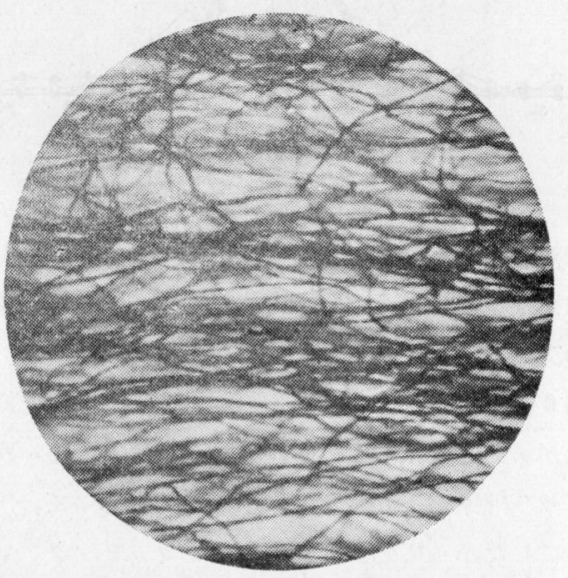

(写真 3 ) 第 3 練条スライバ
ラップの差の大さいのは開打綿による效果及びカレン ダローラによる圧縮のためであり，その後の工程で鳔 準偏差の差が漸減するのはドラフトにより瀻維の卷縮が 伸ばされ，有效要素の配向角が漸次小さくなることに起 因するものと考えられる.

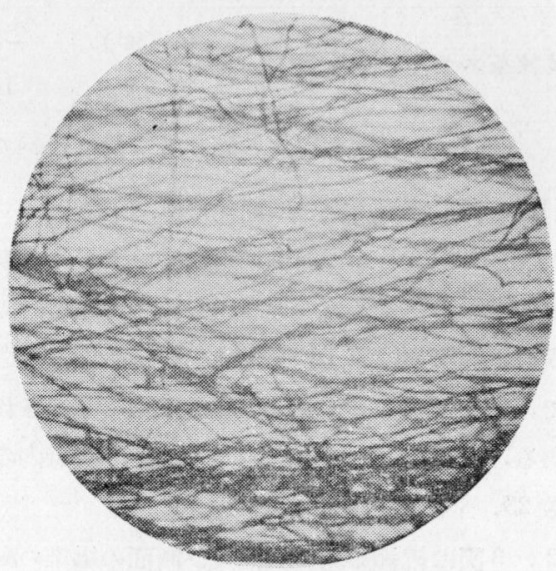

(写 真 4) 第 5 練条スライバ

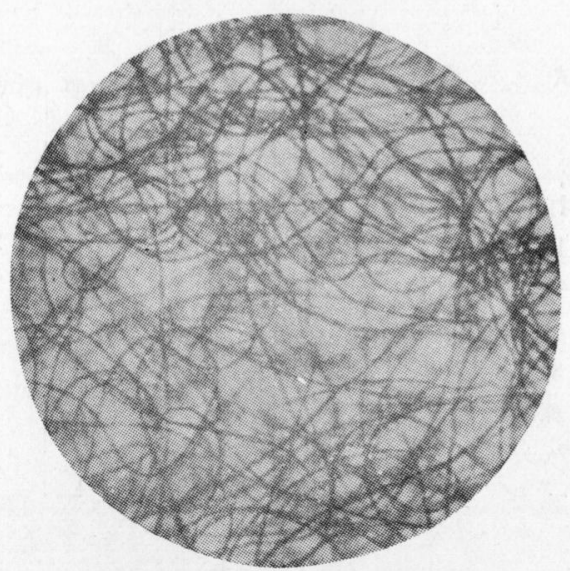

(写真 5) 仕上ラップ

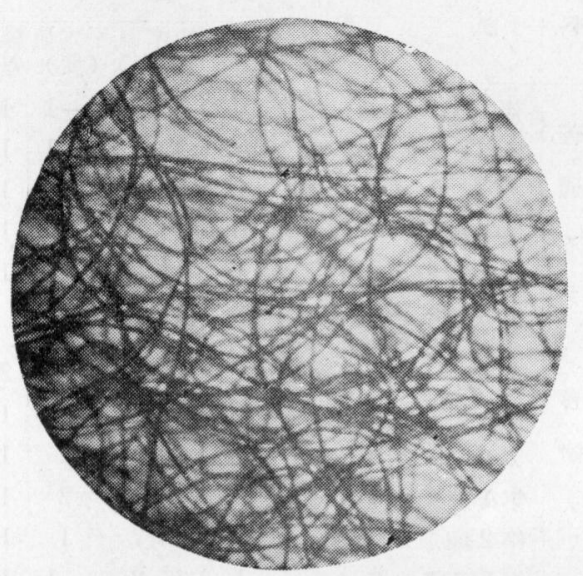

(写真 6) カードスライバ 


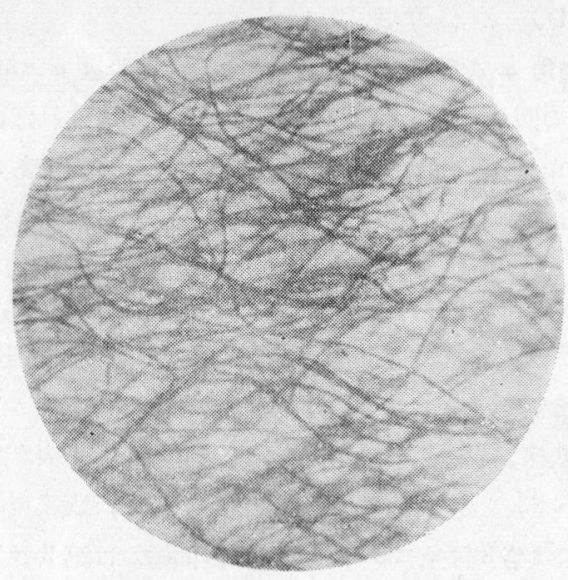

(写真 7) 第 2 練条スライバ

乌真 1 〜 はO 社で製造された米綿（有效瀻維長

1 1/16 in) 瀻維束, 写真 $5 〜 7$ は社で製造された卷縮ス

フ ( 3 den, $2 \frac{1}{4}$ in) 繊維束の表面淺維の顕微鏡写真に

して，写真の実直径は $2 \mathrm{~mm}$ である。

\section{(C) 各工程繊維束の配向角の分布の型}

第 4，5図は綿緎維束の表面及び断面の配向角の累積 相対度数を正規確紙にプロットしたもので，ラップ，カ ードスライバ更びロービングの分布はほとんど直線と なるからこれらの瀻維束の配向角の分布は正規分布に したがい, 練条スライバの分布は $\mathrm{S}$ 学型となるから, 配 向角は正規分布よりもスライバの長さ方向の近くに密集 していることが認められる。

次にこれらの度数分布は正規分布に拉ける本均值，槽 準偏差の 2 個の母集団常数を会んでいると想定し，正規 分布に適合しているや否やを $x^{2}$ 検定により判定する。 第 8,9 表は度数分布の階級が $k$ のとき自由度は $k-3$ と し, 有意水準 0.01 の場合について計算したものである.

瀻維束の表面繊維の分布は原料によって異なるが，大 体ラップ,カードスライバなど工程の最初のものは正 規型，ドラフト工程を経た練条スライバは不正規型であ るが，更にドラフト工程を経るにしたがって正規型に近

表)

\begin{tabular}{|c|c|c|c|c|c|c|c|c|c|}
\hline \multirow{2}{*}{\multicolumn{2}{|c|}{ 試 }} & \multicolumn{2}{|c|}{ 表 } & \multicolumn{2}{|c|}{ 面 } & \multicolumn{2}{|c|}{ 断 } & \multicolumn{2}{|c|}{ 面 } \\
\hline & & 自由度 & $x^{2}$ & $x_{0}^{2}$ & 判 定 & 自由度 & $x^{2}$ & $x_{0}^{2}$ & 判 定 \\
\hline 原 & 綿 & & 25.4 & & & & 21.3 & & \\
\hline 荒 & 打 ラ ッ プ & 15 & 26.2 & 30.58 & 正 規 & 9 & 19.1 & 21.67 & 正 規 \\
\hline & 上 $ラ \%>^{\circ}$ & & 16 & & $\zeta \mathbb{I}$ 阮 & & 47.2 & & 不正規 \\
\hline カ & ードスライバ & 9 & 21.1 & 21.67 & & 7 & $7 \cdot 9$ & 18.48 & 正 規 \\
\hline 第 & 1 練条スライバ & & 26.7 & & & & 41.3 & & \\
\hline 第 & 2 練条スラ1バ & 5 & 66 & 15.09 & 不正規 & & 20.4 & & $1+2$ \\
\hline 第 & 3 練条スライバ & & 42 & & & 3 & 17.2 & 11.34 & \\
\hline ス & ラッビング & 4 & 22.9 & 13.28 & & & 21.4 & & \\
\hline F & 一ビ ン グ & 2 & 8.4 & 9.21 & 正 規 & & 1.2 & & 正 規 \\
\hline
\end{tabular}

(第 9 表)

\begin{tabular}{|c|c|c|c|c|c|c|c|c|c|}
\hline \multirow{2}{*}{ 原料 } & & \multicolumn{2}{|c|}{ 表 } & \multicolumn{2}{|c|}{ 面 } & \multicolumn{2}{|c|}{ 断 } & \multicolumn{2}{|c|}{ 面 } \\
\hline & & 自 由 度 & $x^{2}$ & $x_{0}^{2}$ & 判 定 & 自 由 度 & $x^{2}$ & $x_{0}^{2}$ & 判 \\
\hline 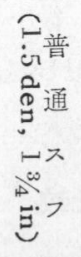 & $\begin{array}{l}\text { 荒 打 } \\
\text { 仕上 } 上 ッ フ ゚ \\
\text { カードスライバ } \\
\text { 第 } 1 \text { 練条スライバ } \\
\text { 第 } 2 \text { 練条スライバ } \\
\text { 第 } 3 \text { 練条スライバ }\end{array}$ & $\begin{array}{l}15 \\
9 \\
5\}\end{array}$ & $\begin{array}{l}44.7 \\
17.8 \\
21.6 \\
41.6 \\
43.1 \\
28.5\end{array}$ & $\begin{array}{r}30.58 \\
21.67 \\
15.09 \\
11.34\end{array}$ & $\left\{\begin{array}{l}\text { 不正規 } \\
\text { 正 規 } \\
\text { 不正規 }\end{array}\right.$ & $\begin{array}{l}5 \\
3 \\
5\end{array}$ & $\begin{array}{r}20.1 \\
40.0 \\
28.9 \\
12.7 \\
11.3 \\
1.8\end{array}$ & $\begin{array}{l}15.09 \\
11.34 \\
15.09 \\
11.34\end{array}$ & $\int^{\text {不正規 }}$ \\
\hline 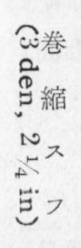 & 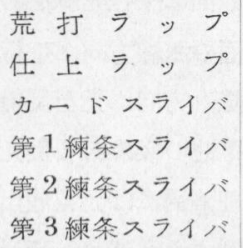 & $\begin{array}{l}7 \\
5\end{array}$ & $\begin{array}{l}30.7 \\
17.2 \\
14.2 \\
10.3 \\
29.1 \\
15.7\end{array}$ & $\begin{array}{l}21.67 \\
18.48 \\
15.09\end{array}$ & $\left\{\begin{array}{l}\text { 不正規 } \\
\text { 正 規 } \\
\text { 不正規 }\end{array}\right.$ & $\begin{array}{l}3 \\
5\end{array}$ & $\begin{array}{r}14.7 \\
26.6 \\
16.6 \\
12.0 \\
9.0 \\
19.5\end{array}$ & $\begin{array}{l}11.34 \\
15.09 \\
11.34\end{array}$ & $\begin{array}{l}\text { 不正規 } \\
\text { 正 規 } \\
\text { 不正規 }\end{array}$ \\
\hline
\end{tabular}




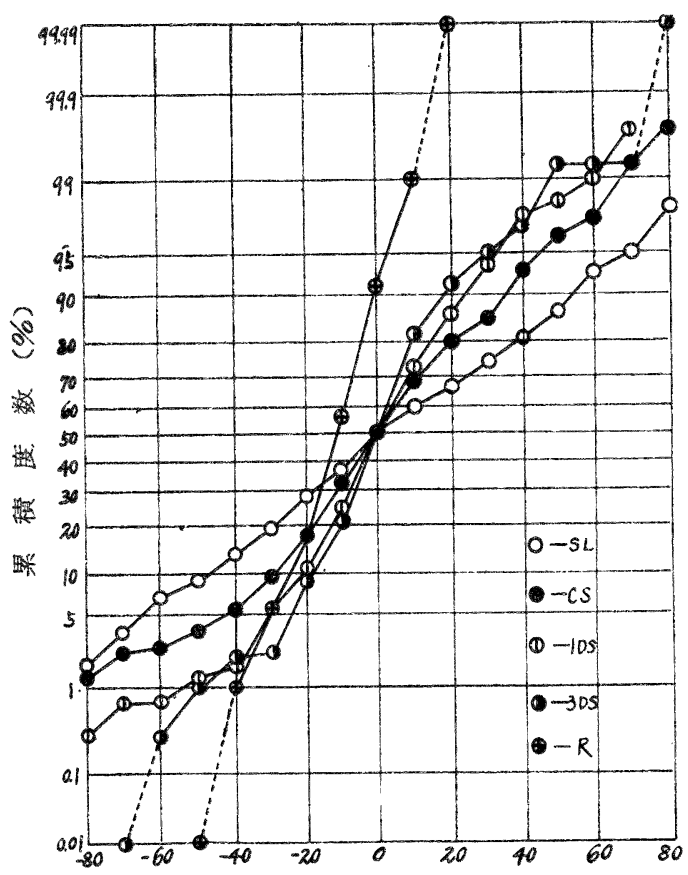

配向角 (度)

（第 4 困）

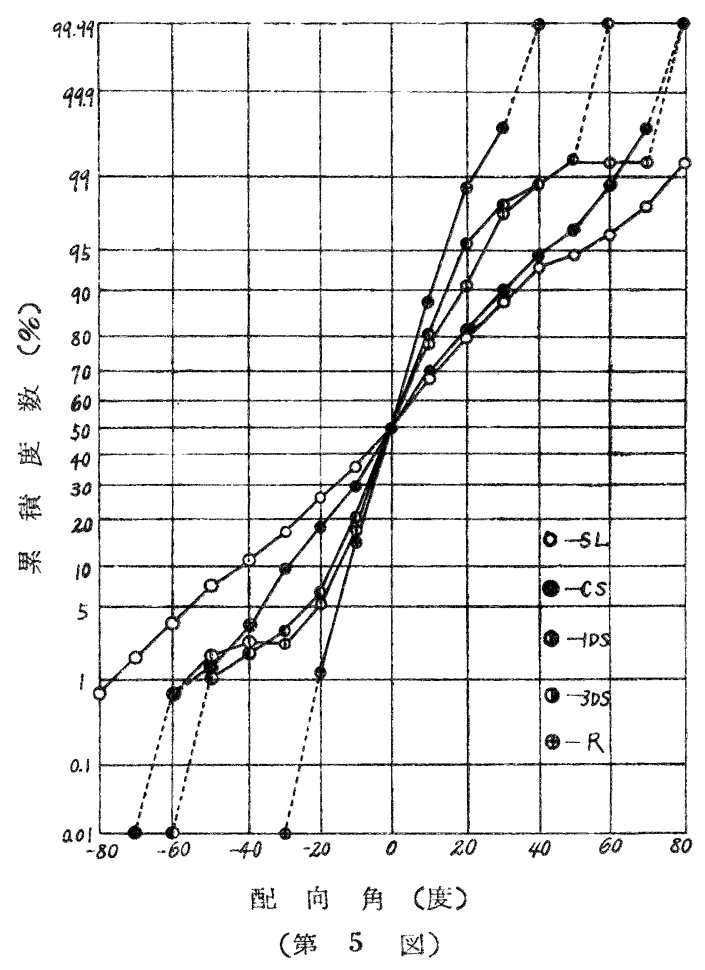

似与る傾问が認められる。

断面繊維の分布は注とんど不正規型にして，開打綿作 用及びカレンダローラによる氏樎などの效果が优の原 因に対して顕著であるためと考えられる。
(D)とがり度

配向角 $\alpha$ を確等变量と見なし， $\mu_{r}$ を変量 $\propto$ の本均

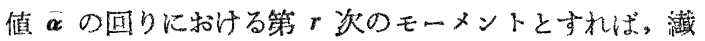
維束の配向角の度数分布のとがり度 $\beta_{2}$ は次式であら方 される。

$$
\beta_{2}=\frac{\mu_{4}}{\mu_{\mathrm{a}}^{2}}=\frac{1}{N} \Sigma f_{i}\left\{\frac{\alpha_{i}-\bar{\alpha}}{\sigma}\right\}^{4}
$$

ただ $f_{i}$ は配向角 $\alpha_{i}$ の頻度数, $\sigma$ は䌘準偏差, $N$ は全祭本数, $\mu_{r}=\frac{1}{N} \Sigma f_{i}\left(\alpha_{i}-\alpha\right)^{r}$ である.

第 10 表は綿紡績各工程の瀻維束 (第 1 報第 1 表参照) について, とがり度 $\beta_{2}$ を匴したすので, 算戴維束の表 面瀐維は第 3 練条スライバまで，断面瀻維は第 2 練条、 ライバまで，工程を経るにしたがってとがり度は増加す るが，以後の工程では漸次減少することが認められる。

$$
\text { (第 } 10 \text { 表) }
$$

\begin{tabular}{|c|c|c|c|}
\hline \multirow{2}{*}{ 試 } & $\varepsilon \quad$ s & $n$ & 度 \\
\hline & 表 & 断 & 面 \\
\hline 綿 & 1.92 & & .13 \\
\hline 兟打 & 2.19 & & .76 \\
\hline 仕上 & 2.41 & & .84 \\
\hline カードスライバ & 3.36 & & .38 \\
\hline 第 1 練条スライバ & 6.84 & & .92 \\
\hline 第 2 練条スライバ & 5.62 & & .05 \\
\hline 第 3 練条スライバ & 6.39 & & .63 \\
\hline スラッビング & 5.92 & & .21 \\
\hline ロ - ビング & 2.77 & & .12 \\
\hline
\end{tabular}

ラップ 及びカード スライバの表面瀻維の有効管素の 標淮偏差は大で，その分布は正規型であるが，カードの カレンダ ドラフト及び練条機のドラフトにより䋊維唒己 列は潮次良好となり，有効要素はドラフト方向に潮次密 集した分布となるため，分布は不王規型となり，とがり 度は濑次大となるが，その媵の工程では繊維配列が著し く良好であるため，ドラフトによる有効要素の配向效果 は潮次娍少し，測定誤差，緎維の亲形の回復なぞ，微小 原因の差が小となるため，分布は潮次正規型に近似し， とがり度も泍次減少するものと考光られる。

\section{Orchard及び石川氏の案驗結果との.比較}

Orchard はカードウェブ表面に本行光線をあてると 大射面 (大射光線とウェブ表面の法線方向汇本行な面) に垂直な瀻維のみが瀻維軸に垂㨁方向に光を反射または 屈折させる.この光を增门光電池の後にある集光レンズ により一点に集中させると，理論的には光電池出力は入 射面汇垂直な瀻維の長さに比例すると述へ，普通スフの 
カードウエブについて入射面を回転させて，第6図の ような繊維の方向分布を計測している。

このグラフから各方向の光電池出力の累積相対度数を 計算し，正規確卒紙にプロット寸れば，第7四の上うに ほとんど直線となり，繊維の方向分布は正規型と見なさ れる。

石川氏は光沢計の大射光線の方向に対する梳毛トップ の方向を種々に变えて，第8四のよ5に各方向の光沢度 を測定している。梳毛トップはほとんど長さ力向に繊維 が配列し，光沢度の入射光線の方向々一致するため，そ の方向で光沢度は最大, 直角方向で最小となると述べて いる.このグラフから各方向の光沢度の累䅡相対度数を 計算し，正規確率紙にプロットすれば，第7図のように 注とんど直線となり，分布は正規型と見なされる。

これらの分布は筆者の測定した普通スフ及びメリノ トップの有效要素の配向角の分布に比べて，いずれも瀻 䊒の散布度は多少大であるが，分布の型はいずれも正規 犁で一致している。（スフ收び羊毛瀐維の有胶要素の長 さははぼ $1.5 \mathrm{~mm}$ 及び $4 \mathrm{~mm}$ とした）

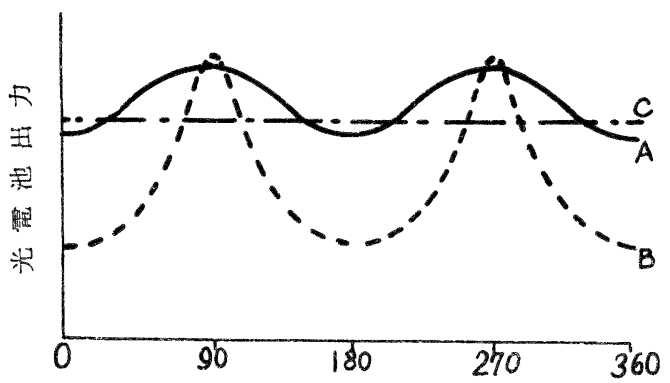

回期 角 (度)

(第6図) A 情末伸長スフカードウェブ，B江伸 長スフカードウメブ, C 沬試料なし

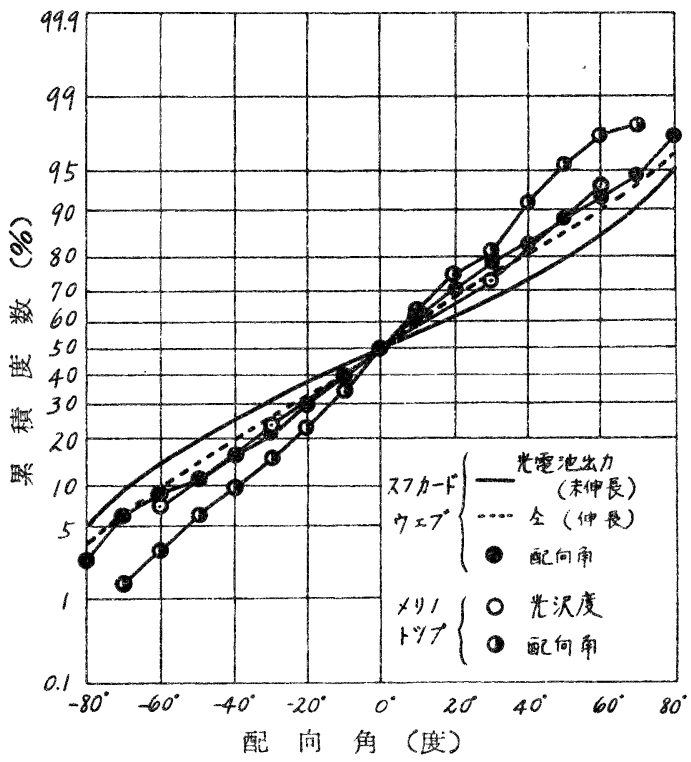

(第 7 汹)

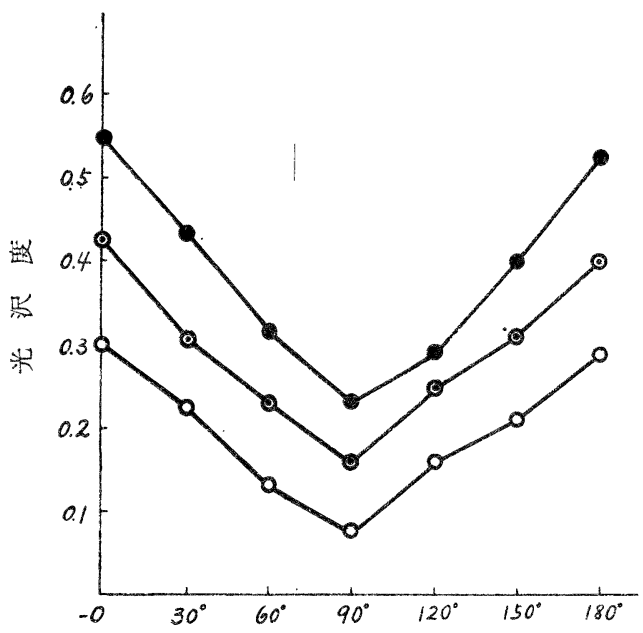

入射光線の方向

(第 8 図) スライバの長さ方向は $0^{\circ}\left(180^{\circ}\right)$ である

このように散布度が相違する原因として（1）描画円 內の瀐維は曲っているが，直線と見なしたこと（2)瀻 維及び繊維束表面の形状は複雑であって，投射光の反射 欧属折が理想的に行われないことなどが考学られる。

\section{5. 結嘒}

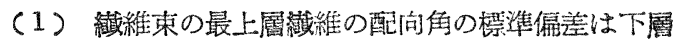
のものより大であるが，綐断面の横方间の位置化よる楔 淮偏差の差はほとんぞ認められない，有效要素は長い结 ぞ，頭徵鏡の偣率は小さい注ど嫖準偏差は小さい。

（2）紡績工程を経るにしたがって, 配向角の標蛪偏 羑は小となり，その減少率も漸次小となる。

(3) 繊維束の表面及び断面瀻維の標淮偏差の差は工 程を経るにしたがって潮次減少する。

（4）紡繈工程初期の瀻維束の配向角の分布は正規型 であるが，工程を経るにしたがって不正規型となり，粗 系ではまた正規型に近似する。

（5）配向角の分布のとがり度は工程を経るにしたが って増加し, 練条機 2,3 回通しで最大となり，その後 潮次減少玄る。

(6) Orchard 及び石川氏の光学的測定法によるス フカードウエブ及び羊毛トップの驖維の散布度は筆者 の測定した有效要素の散布度より多少大であるが，いず れの分布る正規型となった。

本報は昭和 28 年 11 月本学会研究発表会で発表したも のである。

\section{参者交献}

1) W. E. Morton, R. J. Summers : J. Text. Inst., ibid., (1949-40) (1950-41)

2) 石川: 㵶学誌, (昭27-6)

$3)$ G. A. J. Orchard : J. Text. Inst., (1953-8 9)

4) 佐藤：数理統計学概説, P. 16 